\title{
The Effectiveness of Granting Funding at Foundation School / Raudhatul Athfal Bina Kreatif Institution in Batang Kuis District, Deli Serdang Regency
}

\author{
Rosida Sitorus $^{1}$, Heri Kusmanto ${ }^{2}$, Isnaini ${ }^{3}$ \\ Public Administration, Master Study Program, Universitas Medan Area, Indonesia
}

\begin{abstract}
This study aims to evaluation the Effectiveness of Granting Funding at Foundation School / Raudhatul Athfal Bina Kreatif Institutions in Batang Kuis District, Deli Serdang Regency. This study uses the Research Instruments In qualitative research, the main instrument is the researcher himself, but the research instrument that the researcher uses to complement the data and compare it with the data that has been found through observation guidelines, interview guidelines, study and review of documents related to the object of research. Sources of data used in this study are divided into two sources, namely primary data sources and secondary data sources. The results of this study indicate that 1.The benefits of providing grant funds for schools at RA Bina Kreatif Educational Institutions/Foundations in Batang Kuis District, Deli Serdang Regency. 2.There were obstacles in the use of grant funds by RA Bina Kreatif schools in providing grants to schools. 3.The Head of Raudhatul Athfal Bina Kreatif has submitted an Accountability Report Number: 075 / RA-BK / SEK / $V / 2019$. Date, May 20, 2019, regarding the submission of the 2019 APBD-SU Financial Accountability Report.
\end{abstract}

Keywords

grant form social assistance; Raudhatu Athfal Bna Kreatif

\section{Introduction}

Humans as creatures created by God Almighty who have the task of managing and maintaining the universe with full piety and full responsibility are awarded human rights to ensure the existence of dignity and dignity of themselves and the harmony of their environment. In the 1945 Constitution of the Republic of Indonesia Article 28A states that human rights are basic rights that are owned by everyone, where everyone has the right to live and has the right to defend his life and life. However, the social problems that develop today show that there are citizens whose rights to their basic needs are not evenly fulfilled, which causes citizens to experience obstacles in the implementation of social functions so that they cannot lead a decent and dignified life. Thus, it is regulated in Article 34 Paragraph 1 and 2 of the 1945 Constitution of the Republic of Indonesia that the poor and neglected children are cared for by the state, and social welfare is one of the human rights, thus social welfare development is a manifestation of efforts to achieve the goals of the nation as mandated in the 1945 Constitution of the Republic of Indonesia. The fifth precept of Pancasila states that social justice is for all Indonesian people.

In addition, the mandate is that the neglected people are looked after by the state, and the state develops a social security system for all people and empowers the weak and underprivileged people according to human dignity. For the poor and neglected children as mentioned above, the government and local governments are obliged to provide social rehabilitation, social security, social empowerment, and social protection as a 
manifestation of the implementation of the state's obligation to ensure the fulfillment of the basic needs of poor and underprivileged citizens. According to Martinelli at al (2019) Social factors that become priority parameters include; in what fields property is developed, independently or in cooperation, if the cooperation to which party is invested, and so on.

In implementing grant aid to achieve effective and accountable management, the Ministry of Home Affairs has issued Permendagri Number 32 of 2011 which was enhanced by Permendagri Number 13 of 2018. Regarding the third amendment to the Regulation of the Minister of Home Affairs Number 32 of 2011 concerning Guidelines for Grants and Social Assistance sourced from the Regional Revenue and Expenditure Budget. The two Permendagri are then followed up through the Governor of North Sumatra Regulation Number 7 of 2019 dated 15 February 2019 concerning Management Procedures for Interest, Subsidies, Grants, Social Assistance, Profit Sharing, Financial Assistance and Unexpected Expenditures sourced from the Regional Revenue and Expenditure Budget. North Sumatra Province. This formal reference gives a signal to local governments to be more serious in managing grant funds so that the absorbed budget is used according to their goals and objectives.

The phenomenon of the lack and ineffectiveness of the money requested is Rp. $82,430,000,-$ according to the request of the head of Raudhatul Athfal with the Request for Budget Plan:

Table 1. Application for Budget Plan

\begin{tabular}{|c|l|c|r|r|}
\hline No. & \multicolumn{1}{|c|}{ Name of Material } & $\begin{array}{c}\text { Total } \\
\text { Goods }\end{array}$ & $\begin{array}{c}\text { Price } \\
\text { Unit }(\mathbf{R p})\end{array}$ & \multicolumn{1}{c|}{$\begin{array}{c}\text { Total } \\
(\mathbf{R p})\end{array}$} \\
\hline 1 & Cement & 60 sacks & 50.000 & 3.000 .000 \\
\hline 2 & Brick & 20.000 & 500 & 10.000 .000 \\
\hline 3 & Sand & 5 cold disel & 500.000 & 2.500 .000 \\
\hline 4 & Iron 10 ml & 20 sticks & 90.000 & 1.800 .000 \\
\hline 5 & Gravel & 5.000 & 800.000 & 1.600 .000 \\
\hline 6 & Pavinblok Stone & 1 & 1.200 & 6.000 .000 \\
\hline 7 & Iron Fence & 1 & 4.500 .000 & 4.500 .000 \\
\hline 8 & Round Iron Swing & 1 & 2.000 .000 & 2.000 .000 \\
\hline 9 & Globe & 1 & 1.670 .000 & 1.670 .000 \\
\hline 10 & Slides & 2 & 1.500 .000 & 1.500 .000 \\
\hline 11 & Cupboard & 3000 small balls & 1.000 .000 & 2.000 .000 \\
\hline 12 & Bath Ball & 2 & 500 & 1.500 .000 \\
\hline 13 & Ball Tub & 90 meters & 250.000 & 1.400 .000 \\
\hline 14 & Outdoor Classroom Canopy & 24 days & 320.000 & 27.000 .000 \\
\hline 15 & 3 Weeks Mason Wages Estimate & 40 pieces & 20.000 & 800.000 \\
\hline 16 & Shiva Chair & 20 pieces & 70.000 & 1.400 .000 \\
\hline 17 & Student Desk & 2 pieces & 915.000 & 1.830 .000 \\
\hline 18 & Whiteboard & 2 pieces & 1.000 .000 & 2.000 .000 \\
\hline 19 & Teacher's Desk & 4 pieces & 300.000 & 1.200 .000 \\
\hline 20 & Teacher's Chair & 5 sheets & 120.000 & 600.000 \\
\hline 21 & Scaffolding Board & 5 sticks & 90.000 & 450.000 \\
\hline 22 & Wood 2x3 & & & $\mathbf{8 2 . 4 3 0 . 0 0 0}$ \\
\hline
\end{tabular}


In accordance with the Governor's Decree Number 188.44/76/KPTS/2019 dated February 18, 2019 Serial number 1229 for Raudhatul Athfal Bina Kreatif Desa Tanjung Sari Jl. Batang Quiz - Lubuk Pakam Dusun II Tanjung Sari Kec. Batangkuis Kab. Deli Serdang can only help in the amount of Rp. 70,000,000, - with the allocation in accordance with the Budget Plan (RAB) which is obtained and utilized as much as possible, namely the Budget Plan with the approved cost:

Table 2. Budget Plan with the Approved Cost

\begin{tabular}{|c|l|c|r|r|}
\hline No. & \multicolumn{1}{|c|}{ Name of Material } & $\begin{array}{c}\text { The Amount of } \\
\text { Goods }\end{array}$ & \multicolumn{1}{c|}{$\begin{array}{c}\text { Unit Price } \\
(\mathbf{R p})\end{array}$} & \multicolumn{1}{c|}{$\begin{array}{c}\text { Total } \\
(\mathbf{R p})\end{array}$} \\
\hline 1 & Cement & 60 sacks & 50.000 & 3.000 .000 \\
\hline 2 & Brick & 20.000 pieces & 500 & 10.000 .000 \\
\hline 3 & Sand & 5 cold & 500.000 & 2.500 .000 \\
\hline 4 & Iron & 10 milli & 90.000 & 1.800 .000 \\
\hline 5 & Gravel & 2 cold diesel & 800.000 & 1.600 .000 \\
\hline 6 & Pavinvblok stone & 5000 pieces & 1.200 & 6.000 .000 \\
\hline 7 & Iron fence & 1 piece & 4.670 & 4.670 .000 \\
\hline 8 & Canopy & 50 m & 300.000 & 27.000 .000 \\
\hline 9 & Scaffolding board & 5 btg & 120.000 & 600.000 \\
\hline 10 & Wood 2x3 & 2 pieces & 1.000 .000 & 450.000 \\
\hline 11 & Teacher's desk & 4 pieces & 300.000 & 2.000 .000 \\
\hline 12 & Teacher's chair & 1 piece & 1.500 .000 & 1.200 .000 \\
\hline 13 & Slides & $\mathbf{3}$ people & $\mathbf{3 2 0 . 0 0 0 x 2 4}$ & $\mathbf{7 . 6 8 0 . 0 0 0}$ \\
\hline $\mathbf{1 4}$ & Worker wages & & & $\mathbf{7 0 . 0 0 0 . 0 0 0}$ \\
\hline
\end{tabular}

Based on the description above, the researchers saw that the grant funds were ineffective because the institutions or foundations could not fulfill some of the needs of the Raudhatul Athfal Bina Kreatif institution which greatly assisted the teaching and learning process which should include:

Table 3. Grant Funds

\begin{tabular}{|c|l|c|r|r|}
\hline $\begin{array}{c}\text { No. } \\
\text { Sort }\end{array}$ & \multicolumn{1}{|c|}{ Name of Material } & $\begin{array}{c}\text { The amount of } \\
\text { goods }\end{array}$ & $\begin{array}{c}\text { Unit price } \\
\text { (Rp) }\end{array}$ & Amount (Rp) \\
\hline 1 & Round Iron Swing & 1 & $2,000,000$ & $2,000,000$ \\
\hline 2 & Globe & 1 & $1,670,000$ & $1,670,000$ \\
\hline 3 & Cupboard & 2 & $1,000,000$ & $2,000,000$ \\
\hline 4 & Bath Ball & 3000 small balls & 500 & $1,500,000$ \\
\hline 5 & Ball tub & 2 & 700,000 & $1,400,000$ \\
\hline 6 & Shiva chair & 40 pieces & 20,000 & 800,000 \\
\hline 7 & Student desk & 20 pieces & 70,000 & $1,400,000$ \\
\hline 8 & Whiteboard & 2 pieces & 915,000 & $1,830,000$ \\
\hline \multicolumn{4}{|c|}{ Total } & $\mathbf{1 2 , 4 3 0 , 0 0 0}$ \\
\hline
\end{tabular}

Although not fully approved because of the limited financial capacity of the Regional Government. With limited grants, the recipients of the Grants should be able to maximize their use, so that even though their use is limited, they can effectively benefit the recipients. In fact, the Chairman of Raudhatul Athfal Bina Kreatif used these funds for more effective purposes and maximized the existing budget. In application, it is necessary 
to hold an evaluation that is oriented towards the achievement of results (outcomes) which do not provide planned results and the function of the institution is not optimal so that the purpose of the provision is achieved as expected organization is not achieved.

The reason for the ineffectiveness is indicated to occur because 1) There is a use that is not right on target/not according to its designation. 2) Utilization is not in accordance with the stipulated plan. 3) The implementation of activities is late/hampered. So that it affects the achievement of the goal of receiving grant funds for schools to grant recipients, to educational institutions and foundations that are not optimal, so the function or utilization is not properly implemented.

\section{Review of Literatures}

\subsection{Definition of Grants and Social Assistance}

The definition of grants and Social Assistance Grant Funds is the provision of money/goods or services from the local government to the government or other local governments, local companies, communities and community organizations, which have been designated for specific purposes, are not mandatory and are not binding, and are not continuous which aims to support the implementation of regional government affairs.

According to Ismail et al (2020) Community empowerment, such as the task of socializing the community in the fields of culture, economic politics, maintaining partnership relations with community institutions with other institutions. According to Angelia (2020) In order to implement the development program according to regulations and guidelines, synergy with the community cannot be ignored.

Social assistance is the provision of assistance in the form of money/goods from the regional government to individuals, families, groups and/or communities which are not continuous and selective in nature with the aim of protecting against possible social risks. Permendagri Number 13 of 2018 concerning the Third Amendment to the Regulation of the Minister of Home Affairs Number 32 of 2011 concerning Guidelines for Providing Grants and Social Assistance sourced from the Regional Revenue and Expenditure Budget, a grant is the provision of money/goods or services from the Regional Government to the central government or other local governments, State-Owned Enterprises/Region-Owned Enterprises, Entities, Institutions and Community Organizations with Indonesian Legal Entities which have been specifically designated for designation, are non-obligatory and non-binding, and are not continuously aimed at supporting the implementation of regional government affairs. Social assistance is the provision of assistance in the form of money/goods from the regional government to individuals, families, groups and/or communities that are not continuous and selective in nature, aiming to protect against possible social risks. General provisions for grants according to Permendagri Number 13 of 2018 concerning the Third Amendment to the Regulation of the Minister of Home Affairs Number 32 of 2011 concerning Guidelines for Providing Grants and Assistance Social, which is sourced from the Regional Revenue and Expenditure Budget, grants are intended to support the achievement of regional government program and activity targets by taking into account the principles of justice, appropriateness, rationality, and benefits for the community. According to Permendagri Number 13 of 2018 concerning the Third Amendment to the Regulation of the Minister of Home Affairs Number 32 of 2011 concerning Guidelines for Providing Grants and Social Assistance sourced from the Regional Revenue and Expenditure Budget which states that grant recipients are responsible. 


\subsection{Purpose of Grants}

In accordance with the definition of a grant, the provision of a grant by the regional government aims to support the implementation of regional government affairs. Grants are intended to support the achievement of targets for government programs and activities while still paying attention to the principles of justice, appropriateness, rationality and benefits for the community, as well as in accordance with the principles of regional financial management. These principles can be explained as follows:

1. The principle of justice, namely there is a balance in the distribution of authority and its distribution and/or a balance in the distribution of rights and obligations based on objective considerations;

2. The principle of fairness is an action or attitude that is carried out fairly and proportionally;

3. The principle of rationality, namely the decision on the grant of a grant must be right on target and can be accounted for;

4. The principle of benefit for the community, namely that regional finances must be prioritized to meet community needs and be beneficial;

5. The principle of regional financial management means that regional finances are managed in an orderly manner, obeying laws and regulations, are effective, efficient, economical, transparent, and accountable by taking into account the principles of justice, appropriateness and benefits for the community.

\subsection{Grant Form}

According to Permendagri Number 13 of 2018 concerning the Third Amendment to the Regulation of the Minister of Home Affairs Number 32 of 2011 concerning Guidelines for Providing Grants and Social Assistance sourced from the Regional Revenue and Expenditure Budget which states that grant recipients are formally and materially responsible for the use of the grants they receive. The form of the grant can be described as follows:

1. Grants in the form of money, budgeted in indirect expenditure groups, types of grant expenditures, objects of grant spending, and details of objects for grant expenditures at the Regional Financial Management Officer is the head of the Regional Financial Management Work Unit which has the task of implementing management Regional Revenue and Expenditure Budget and act as regional general treasurer. Grants in the form of money are grouped into indirect expenditures, which are expenditures that are not directly related to the implementation of regional programs and activities.

2. Grants in the form of purchases of goods and/or activities in the form of services, are budgeted for in a group of direct expenditures formulated into programs and activities, which are elaborated into types of goods and services expenditures, objects of goods or services grant expenditures relating to third parties/communities, and details of objects Grant expenditures for goods or services submitted to third parties/communities in Regional Work Units. Regional Work Units is a regional apparatus in local government as budget user/user of goods. Grants in the form of goods and/or services can be grouped into direct expenditures, which are expenditures that are directly related to the implementation of regional programs and activities.

\subsection{Utilization}

Utilization is a derivative of the word 'Benefit', which is a tapping which merely shows the activity of receiving. The interception generally leads to the acquisition or use of things that are useful either directly or indirectly in order to be useful. Meanwhile, 
according to Prof. Dr. J.S. Badudu in the General Indonesian Dictionary, says that: "Utilization is a thing, a way, a result of work in utilizing something useful". And another definition of benefits issued by Dennis Mc Quail and Sven Windahl, namely: "Benefit is hope which means the same as explore (confrontation merely shows an activity of receiving)". In addition, Dennis also said that there are two things that encourage the emergence of an use, namely:

1. There is opposition to the deterministic view of the mass media effect.

2. Meanwhile, the second is the desire to escape from prolonged debate about the tastes of the mass media.

And if it is related to the problem of this research, then the use here means using or using something useful which in this case is to use or use brochures as a medium in conveying information to the public, namely customers who are one of the external publics. From the use of brochures as a medium in conveying information to the public, it is hoped that it can provide results in the form of useful knowledge for the public who reads them, in this case the customers of Carrefour. So that customers know about the products the company offers through brochures.

\section{a. The Purpose of Using the Database}

The objectives of using the database are:

1. Speed and Ease (speed). Namely so that database users can:

1) save data

2) make changes/manipulation of data

3) display back data faster and easier than the usual way (either manual or electronic).

2. Efficiency of Storage Space (Space). With databases we are able to emphasize the amount of redundancy (repetition) of data, either by applying a number of encodings or by creating relationships between interconnected data groups. So that data conforms to certain rules and limitations by utilizing coding or forming relationships between data along with the application of rules/constraints on data types, data domains, data uniqueness, etc.

3. Availability. So that data can be accessed by every user who needs it, with the application of network technology and transfer/delete data that is no longer used/expired to save storage space.

4. Completeness. So that the managed data is always complete, both relative to user needs and to time, by adding data rows or making structural changes to the database; namely by adding fields to the table or adding a new table.

5. Security. So that confidential data or vital processes do not fall to unauthorized persons/users, namely by using accounts (username and passwords) and applying differentiation of each user's access rights to data that can be read or processes that can be carried out.

6. Togetherness (Sharability). So that the data managed by the system supports a multiuser environment (multiple users), by maintaining/avoiding the emergence of new problems such as data inconsistencies (due to changes data performed by several users at the same time) or deadlock conditions (because there are many users waiting for each other to use data). (https://ikakyuda n.d.)

\section{b. Database and Definition}

1. Representation of world facts that represent an object recorded in the form of numbers, letters, symbols, text, images, sounds or a combination.

2. Headquarters/gathering place/nesting place/warehouse. 
3. The set of data groups (archives) that are interconnected which are organized in such a way so that later they can be reused quickly and easily.

Collections of interrelated data stored together in such a way and without unnecessary redundancy to meet various needs.

\section{c. Database and Filing Cabinets}

1. The database can be thought of as a filing cabinet with various ways of organizing it

2. The database and filing cabinets have the same working principles and goals; in principle, namely the arrangement of data/archives. The main objective is the ease and speed of retrieving data/archives.

\section{Research Methods}

This study uses the Research Instruments In qualitative research, the main instrument is the researcher himself, but the research instrument that the researcher uses to complement the data and compare it with the data that has been found through observation guidelines, interview guidelines, study and review of documents related to the object of research.

Therefore, in finding the evaluation of grants for schools at RA Bina Kreatif Educational Institutions/Foundations in Batang Kuis District, Deli Serdang Regency. Researchers must find data related to research in depth, and do not emphasize generalized judgments, but rather emphasize meaning.

Sources of data used in this study are divided into two sources, namely primary data sources and secondary data sources.

1. Primary Data

Primary data is the main data in research, the primary data source in the study is the results of observations, interviews with respondents, and documentation at the RA Bina Kreatif Educational Institution/Foundation in Batang Kuis District, Deli Serdang Regency.

2. Secondary Data

Secondary data are various other data sources that are still related to this research later. Among them, the internet, journals, books, magazines, newspapers and so on.

The data collection technique used the person activity method by researchers to capture and obtain data from complete personal activities regarding the Evaluation of Grants for Schools against RA Bina Kreatif Educational Institutions / Foundations in Batang Kuis District, Deli Serdang Regency, where data collection techniques were carried out through observation/observation, interview and document review (Sugiyono (2015: 308).

3. Interview

Interview intends to construct about people, events, organization, feelings, motivations, demands, concerns and others. Interviews to answer the problems in this study were carried out to informants from village officials who were related to this research. To make it easier to get research data and answers. Researchers used the semi interview type structured.

4. Observase

In a psychological sense, observation or what is also called observation, includes the activity of loading attention to an object by using all the sense organs. So, observing can be done through sight, smell, hearing, touch, and taste. What this says is actually an observation live. 


\section{Results and Discussion}

The teaching and learning process occurs because there is a process of educational transformation and creates a comfortable atmosphere. In the learning process at the kindergarten or early childhood level, extra high patience is needed for students with the aim that the child's memory becomes sharper to deliver to the elementary school level. In this process there needs to be adequate infrastructure support and support from the government to make value benefits for teachers and students. So that social assistance has its beneficial value. This is in accordance with the general provisions of grants, according to Permendagri Number 32 of 2011, giving grants is intended to support the achievement of program and activity targets. Local government with pay attention to the principles of justice, propriety, rationality, and benefits to society. According to Article 19 Permendagri No. 32 of 2011 concerning the Provision of Grants and Social Assistance which states that the recipient of grants is formally and materially responsible for the use of the grants they receive.

The results showed that the benefits of providing grant funds to RA Bina Kreatif Educational Institutions / Foundations were due to:

1. Lack of budget for school repairs. Inadequate need for facilities and infrastructure in RA Bina Kreatif Education needs government attention, so schools submit a proposal.

2. The demands for school development such as children's games, namely swings, globe, ball baths and school facilities such as student chair cabinets' whiteboarrd student desks all support the success of the process learning to teach the sustainability of the RA Bina Creative Education foundation to be more effective.

This identifies that the need in private schools is also a need and demand for adequate teaching and learning activities and requires the government to provide support for the future of education. The need for teacher salaries, and stationery as well as facilities that are a burden to the foundation which is not strong enough to bear it alone while the government is also not able to provide all of it, the participation of the private sector is a serious concern for the government which is expected by the private sector because the value of benefits provided is expected.

But apart from that mentioned above, the provision of social assistance as referred to in Article 22 paragraph (1) meets the criteria of being at least selective, fulfilling the requirements of the recipient of assistance. All of these must understand the existing relationships, as put forward by Suharto (2014: 66) in the context of social work, empowerment can be done with three levels or dimensions of empowerment, namely

1. Micro Level. Empowerment is carried out on individual clients through guidance, counseling, stress management, crisis intervention. Its main purpose is to guide or train clients in carrying out their life tasks

2. Levels of Mezzo. Empowerment is carried out on a group of clients. Empowerment is carried out using groups as a medium of intervention. Education and training, group dynamics, are usually used as a strategy in increasing the client's awareness, knowledge, skills and attitudes so that they have the ability to solve the problems they face.

3. Macro Level. This approach is also known as the big systems strategy, because the goals of change are directed at the wider environment. Policy formulation, social planning, social action, lobbying, community organizing, conflict management, are some of the strategies in this model.

The goals expected by the RA Bina Kreatif Education Foundation for students provide a sense of comfort and safety for teachers in teaching and educational goals are achieved. For parents to provide a sense of security when leaving their children at school, 
their trust in the school becomes high. So that they are able to face the crisis for each student and parent, empowerment of the group of parents by solving the problem of lack of school together. Planning proposals for social assistance and grants that are mature by means of a strategic approach to various elements, namely parents, teachers and government, to lobby and strategies to avoid distrust.

\section{Conclusion}

1. The benefits of providing grant funds for schools at RA Bina Kreatif Educational Institutions/Foundations in Batang Kuis District, Deli Serdang Regency.

a) Ineffective because the funds received are not in accordance with the proposed Budget Request, so the foundation or manager must recalculate which budget must be worked out first or prioritized so that it can help the teaching and learning process properly and comfortably.

2. There were obstacles in the use of grant funds by RA Bina Kreatif schools in providing grants to schools.

a) The funds provided by the North Sumatra Provincial Government are limited so that the use of the Fund is not entirely sufficient for the Raudhatul Athfal Bina Kreatif Foundation, so the participation of other foundations/sectors that can provide assistance is necessary.

b) Constraints in implementing grant applications require a long process of time, as they go through several stages. And this causes the grant disbursement process that must be passed through several stages, namely requesting assistance with the number: 025/ RA-BK / SEK / XI / 2018. Date. 12 November 2018, the Governor's Decree was issued with the number: 188.44 / 76 / KPTS / 2019. Date. 18 February 2019, with the Governor's letter number: 518 / SP / TU / Sokesra / 2019. Date. February 25, 2019, regarding notification and completing the disbursement file.

3. The Head of Raudhatul Athfal Bina Kreatif has submitted an Accountability Report Number: 075 / RA-BK / SEK / V / 2019. Date, May 20, 2019, regarding the submission of the 2019 APBD-SU Financial Accountability Report.

\section{References}

Anwar, M. oos. Pemeberdayaan Masyarakat di era Global. Bandung: Alfabeta, 2014.

Angelia, et al. (2020). Analysis of Community Institution Empowerment as a Village Government Partner in the Participative Development Process. Budapest International Research and Critics Institute-Journal (BIRCI-Journal), 1352-1359.

Arikunto, Suharsimi. Evaluasi Program pendidikan Pedoman Teoritis Praktis bagi Praktisi Pendidikan. Jakarta: Bumi Aksara, 2004.

Blogsport.co.id. "Artikel Makalah-Belajar." Teori dan Model Komunikasi Organisasi, 2012.

Cangara, Hafied. Pengantar Ilmu komunikasi. Jakarta: Jakarta: Raja Grafindo Persada, 1998 .

David., Fred. R. menejemn strategi. Jakarta: Salemba empat, 2010.

Dharma, Kesuma, dan Teguh, Ibrahim. Struktur Fudamental Pedagogik. 1. Edited by M. Danda Wildani. Vol. 1. Bandung: PT Refika Aditama, 2016.

Dirman, Cicih juarsih. Komunikasi Dengan Peserta Didik. Jakarta: PT Redika Cipta, 2014.

Donni Juni Priansa, dan Agus Garnida, Manajemen Perkantora Efektif, Efisien, dan Profesional, Bandung: Alfabeta, 2013 
Fauzanh. makalah penyuluhan dan komunikasi. blog.co.id/2013, 2013.

Griffin, EM. "A First Look At Communication Theory." By Mc.Graw Hill. New York: www..Afirtlook.com/meet_em, 2003.

George Ritzer dan Douglas J. Goodman, Teori Sosiologi: Dari Teori Sosiologi Klasik Sampai Perkembangan Mutakhir Teori Sosial Modern, trans. oleh Nurhadi (Yogyakarta: Kreasi Wacana, 2009).

Handayaningrat, Soewarno. Pengantar Study Ilmu Administrasi dan Manajemen. Jakarta: Gunung Agung, 1985.

Hasbiansyah. effective communication. Unisba Bandung: Moss, Stewart L.tubbs dan Sylvia, 1996.

https://ikakyuda. materai pendidikan basis data dan defenisi tujuan pemenfaatan basis data.worspress.com, n.d. https://web.facebook.com/notes/ika- namapt/fungsi-dantujuan-ikatan-alumni-untukpengembangan-sekolah. face books, n.d.

Ismail, et al. (2020). The Role of Keuchik in Activity of City without Slum (Kotaku) in Gampong Lampulo Kuta Alam Regency Banda Aceh. Britain International of Humanties and Social Sciences (BIoHS) Journal, 341-350.

Khomson, Ali. Indikator Kemiskinan dan Misklasifikasi Orang Miskin. Jakarta: Yayasan Pustaka Obor Indonesia, 2015.

Manulang, M. Dasar-Dasar Manajemen. Jakarta: Ghalia Indonesia, 1986. Moenir. Manajemen Pelayanan Umum di Indonesia. Jakarta: Bumi Aksara, 2000.

Martinelli, I., et al. (2019). Community Economic Development Prospect Based on Wakaf Funds. Budapest International Research and Critics Institute-Journal(BIRCI-Journal), 409-423.

Moleong, Lexy J. Metodologi Penelitian Kualitatif. cet. 32. Bandung: Remaja Rosdakarya, 2014.

Morissan. Teori Komunikasi Individu Hingga Massa. Vol. 1. Jakarta: Prenandamedia, 2014.

Notowidagdo, Rahiman. Pengantar Kesejahteraan Sosial Berwawasan Iman dan Tagwa. Jakarta: Amzah, 2016.

Onong, Uchjana. Komunikasi teori dan praktek. Bandung: PT. Remaja Rosdakarya, 1999.

Permendagri. Nomor 32 sebagaimana telah diubah dengan Permendagri nomor 39 tahun 2012. 2011.

Rahardjo, Mudjia. "mudjiarahardjo.com." mudjiarahardjo.com/artikel. November 17, 2012. www.mudjiarahardjo.com (accessed Januari 3, 2016).

Rakhmat, jalaluddin. psikologi komunikasi. 1989.

Richard M., Steers. Efektivitas Organisasi. Jakarta: Erlangga, 1985. Robbins, Stephen. Perilaku Organisasi. Jakarta: PT. Prenhallindo, 2001.

Ruben Breat.D, \& Lea.P,Stewart. Komunikasi dan Prilaku Manuasia. Jakarta: PT Raja Grapindo Persada, 2013.

Siagian, Sondang P. Filsafat Adminstrasi. Jakarta: Rineka Cipta, 1997.

Siagian, Sondang. P. bunga Rampai Manajemen Modern. Jakarta: Gunung Agung, 1981.

Siregar, Ashadi. "Kurikulum dan Pengembangan Studi Komunikasi." Lokakarya Kurikulum Jurusan Ilmu Komunikasi FISIPOL UMY. Yogyakarta, Juni 23, 1997.

Sitikholifah. "Komunikasi Pendidikan." http:Blog.Umy.Ac.Id. 11 18, 2012.

http://blog.Umy.ac.id (accessed April 17, 2013).

Soleh, Chabib. Dialektika Pembangunan dengan Pemberdayaan. Bandung: Fokusmedia, 2014.

Sugiyono. Memahami Penelitian Kualitatif. Bandung: Alfabeta, 2008.

—. Metode Penelitian Kombinasi . Bandung: Alfabeta, 2011. 
Suharto, Edi. memebangun Masyarakat Memberdayakan Rakyat Kajian Strategi pembangunan kesejahteraaan Sosial dan pekerjaan Sosial. Bandung: Refika Aditama, 2014.

Sumodiningrat, Gunawan dan. Membangun Perekonomian Rakyat. Yogyakarta: PT Pustaka Pelajar, 1998.

T.Hani, Handoko. Menejemen edisi kedua cetakan ke tujuh. Yogyakarta: BPFE, 1993.

Tohirin. Penelitian Kualitatif dalam pe3ndidikan dan Bimbingan Konseling.

Jakarta: Rajawali Pers, 2013.

UU RI, Presiden. "www.hukumonline.com." hukumonline.com. Juli 8, No. 20 Thn 2003. http://www.hukumonline.com/pusatdata/uu-no-20-tahun-2003-sistempendidikannasional.pdf (accessed Januari 22, 2016).

Warsita, Bambang. Teknologi Pembelajaran: Landasan \& Aplikasinya. Jakarta: Rineka Cipta, 2008.

Weber, Max. "Teori Birokrasi." Isakuikikang.blogsport.co.id, 2014.

Wirawan. Evaluasi, Teori, Model Standar, Aflikasi dan Profesi. Jakarta: Rajawali Press, 2012.

Wiryanto. Pengantar Ilmu Komunikasi. jakarta: Grameja Wilasarana Indonesia, 2005. 